\title{
KUTKEA TARVITAAN MYÖS SOTE-AJASSA
}

\author{
Kuntoutuksen tutkimus- ja kehittämisyhdistys KUTKE ry:n \\ aiemman puheenjohtajan Juhani Wikströmin haastattelu
}

Lokakuisena iltana vuonna 2020 kokoonnuimme Invalidiliiton tiloissa kolmen hengen voimin, aiheena ainutlaatuinen katsaus kuntoutuksen kehittämisen vaiheisiin ja kuntoutuksen uuteen tulemiseen sote-muutoksiin valmistauduttaessa. Juhani Wikström, joka on aiemmin kahdesti ollut vastuussa Kuntoutuksen tutkimus- ja kehittämisyhdistys KUTKE ry:n puheenjohtajan tehtävästä, oli KUTKEn nykyisen puheenjohtajan ja varapuheenjohtajan haastateltavana.

\section{Juhani Wikström, KUTKEn toiminnalle} luotiin pohja 1980-luvulla.

Miten tuota aikakautta voisi kuvailla suhteessa nykyhetkeen, kuntoutuksen näkökulmasta?

Maahamme saatiin 1980-luvulla uudet lait, jotka olivat edistyksellisiä ja muuttivat kuntoutujien asemaa ja palveluita. Tuona ajankohtana kuntoutuksen arvot olivat lähes samat kuin 2020-luvulla. Niitä olivat työntekijöiden asiakaslähtöinen, moniammatillinen ja yhteisöllinen työote. Ihminen haluttiin nähdä subjektina, ei objektina, toimenpiteet haluttiin suunnitella usean ammattilaisen yhteistyönä, ja ympäristön fyysinen ja henkinen esteettömyys alkoi kiinnostaa.

Sosiaali- ja terveysministeriössä (STM) parhaillaan vireillä olevat Kuntoutuksen uudistamiskomitean ehdotukset vuodelta 2017 kuulostavat sen vuoksi tutuilta. Ajassa tapahtunutta edistystä kuvaa se, että entisten painotusten oheen on tuotu entistä vaativampia tavoitteita.

Menneet vuodet vakuuttavat, että KUTKEa tarvitaan. Sen nykyinen kokoonpano, jossa ovat edustettuina käytännön työntekijät, tutkijat, ammattikorkeakoulut, yliopistot ja KELA, on perusta vaikuttamiselle, uusille sosiaalisille innovaatioille ja niiden soveltamiselle sekä koulutukselle. Sillä on käytössään toimikunnat kuntoutuksen erityispätevyyttä, tiedettä, koulutusta, ammatillista ja mielenterveyskuntoutusta sekä viestintää varten. Sillä on myös kansainvälinen yhteistyökumppani EFRR (European Forum for Research in Rehabilitation). Kansainvälisesti katsoen KUTKE on ainulaatuinen yhdistys, muissa maissa ei ole vastaavia kansallisia kuntoutuksen tutkimuksen ja kehittämisen organisaatioita.

KUTKE on ollut kykenevä muutokseen tarpeen vaatiessa. Yhdistyksen rakentuminen nykyisen kaltaiseksi on hidas tapahtuma ja tarvitsee selkeän vision ja ennen muuta luottamusta. Onnistumisen takeena ovat hyvät yhteistyökumppanit menneiden vuosien varrelta. 
KUTKEn nimi oli alussa Suomen lääkinnällisen kuntoutuksen yhdistys ry (SLKY). Mikä on tämän tausta?

Luonnollinen selitys alkuperäiselle nimelle oli se, että perustajat olivat keskussairaaloiden kuntoutustutkimusyksiköiden ylilääkärit ja kuntoutussihteerit. Lähtölaukaus oli vuoden 1984 VALTAVA-uudistus, jolla sosiaalija terveydenhuollon kuntoutuksen palveluita ohjailtiin tulevaan. Vuonna 1987 perustettu yhdistys oli tarkoitettu julkisen terveydenhuollon ammattilaisille. Näin saatiin kuitenkin aikaan valtakunnallinen forum tukemaan paikallista virkatyötä.

Kuntoutustutkimusyksiköiden omat resurssit olivat niukat ja uusien lakien edellyttämät haasteet puolestaan valtavat. Sosiaalihallitukselta siirretyillä resursseilla oli samalla käynnistettävä koko maan laajuinen terveydenhuollon henkilöstön koulutus kuntoutuksen integroimiseksi osaksi eri alojen ja yksiköiden normaalia toimintaa. Asiat etenivät vauhdilla, ja alettiin kaivata epämuodollista ja vapaata foorumia yhteyksien solmimiseen ja innovaatioiden yhteensovittamiseen.

Vaikka SLKY ry oli toimiva, se ei palvellut riittävän hyvin uudistuksen tarkoittamaa monialaista yhteistyötä. Uudet sosiaaliset innovaatiot vaativat lisää osaajia, jotta moniammatilliset, asiakaslähtöiset, yksilön tarpeet paremmin huomioivat ja vaikuttavammat palvelut toteutuisivat. Tavoitteena oli, että toimintamallit myös leviäisivät aktiivisiksi käytännön työotteiksi. Kuntoutumisprosessista haluttiin silta julkisesta terveydenhuollosta kohti ympäröivää yhteiskuntaa ja sen muita palveluita. Näin hoito- ja kuntoutusprosessit saataisiin jatkumaan tarpeen mukaan sosiaalitoimessa, vakuutusjärjestelmässä, työelämässä, oppilaitoksissa ja normaalissa arjessa. Onnistuminen edellytti eri aloilla toimivien ammattilaisten saamista saman pöydän ympärille. Samaan aikaan myös kuntoutuksen tutkijat kokivat voimattomuutta ja yksin jäämistä ja haaveilivat omasta yhdistyksestä asiansa edistämiseksi.

\section{Tehtiin siis toiminnan muutos, joka} näkyi myös nimenmuutoksena?

Uudessa tilanteessa oli luontevaa katsoa SLKY:n toimintaa entistä laajemmasta näkökulmasta. Yksimielisesti päätettiin avata yhdistys kaikille kuntoutuksen ammattilaisille riippumatta siitä, missä organisaatiossa toimi. Mukaan saatiin niin julkisen kuin yksityisen sektorin toimijat, niin kuntouttajat kuin tutkijat. Kuntoutussäätiön tutkijoiden mukaan tulo oli ratkaiseva uuden yhteistyön kannalta. Vuonna 2012 SLKY:n nimeksi tuli Kuntoutuksen tutkimuksen ja kehittämisen yhdistys ry eli KUTKE. Näin saatiin käynnistettyä yhteistyö ja välitön vuorovaikutus kuntouttajien ja tutkijoiden kesken.

KUTKE sai heti kannatusta, sillä laaja-alaiselle verkostolle oli selvästi sosiaalinen tilaus. Siitä muodostui odotusten mukaisesti avoin ja vapaa foorumi asioiden yhdessä pohtimiseen, tavoitteiden asettamiseen ja vaikuttamiseen. Sen avulle kyettiin rakentamaan nopeasti ja tehokkaasti verkostoja eri hallinnonalojen ja asiantuntijoiden välille. Yhdistyksen perustaminen laajensi näkökulmaa, nosti esille asioita, joita voitiin yhdessä edistää, lisäsi vaikuttavuutta, kohensi koulutuksen tasoa ja yhdisti tutkijat ja käytännön työntekijät uusien toimintamallien edistämiseksi. Laajentunut toimintamuoto mahdollisti säännölliset kuntouttajien ja tutkijoiden koulutukset sekä yhdessä että erikseen. Tutkijoiden avulla ammattilaisille järjestetyt tieteelliset tapaamiset toimivat myös hyvänä koulutuspohjana kansainvälisiin tieteellisiin tapahtumiin.

Uusi aika on tuonut uusia haasteita entisten lisäksi. STM:n vuoden 2017 Kuntoutuksen uudistamiskomitean ehdotukset ovat myös KUTKEn asialistalla. Kuntoutus on tärkeässä roolissa, kun sosiaali- ja terveydenhuollossa tavoitellaan kustannustehokkaampaa yhteistyötä ja vaikuttavampia toimenpiteitä ihmisten arjessa pärjäämisen helpottamiseksi. Kuntoutuksen lainsäädäntö ja sen mukaisesti toteutetut käytännöt ovat Suomessa olleet aina myös kansainvälisesti vertailtuna korkeatasoista, mikä sekin on hyvä kannustin uusille sosiaalisille innovaatioille. 
Millaista yhteistyötä on tehty STM:n kanssa, ja mikä rooli on ollut Kuntoutussäätiöllä?

STM:n ja aikanaan Kuntoutusasiain neuvottelukunnan selonteot ovat olleet aina KUTKEn asialistalla ja niihin on reagoitu ja vaikutettu pitämällä yhteyttä asioista vastaaviin virkamiehiin. Kuntoutusasiain neuvottelukunta oli merkittävä tuki ja turva, mutta sen toimeksianto on sittemmin päättynyt. Se ei ole este yhteydenpitoon, sillä ministeriössä on edelleen kuntoutusasioista vastaava virkamies.

Kuntoutuksen tutkimuksen kannalta merkittävää oli neuvottelukunnan tutkimusjaoston työskentely vuosina 2000-2003, jolloin KUTKE oli edustettuna useassa roolissa. Vuoden 2003 raportin valmisti Kuntoutussäätiö STM:n tilauksesta. Näin KUTKEn työ vahvistui myös kuntoutuksen tutkimuksen yhdistyksenä. STM:n tutkimus- ja kehittämisjohtajan aloitteesta KUTKEn yksi tavoitelluimmista toiveista toteutui Suomen Akatemian päättäessä tukea kuntoutuksen tutkimusta. Päätös muutti kuntoutuksen tutkimuksen asenneilmastoa kertaheitolla muidenkin rahastojen osoittaessa tukea kuntoutuksen tieteellistä tutkimusta kohtaan.

Kuntoutussäätiöllä on ollut uraauurtava rooli suomalaisen kuntoutuksen tutkijana ja kouluttajana. Säätiön tutkijoiden aktiivisella panoksella KUTKEen perustettiin tieteellinen toimikunta ja säännölliset monitieteiset tutkijaseminaarit käynnistettiin. KUTKE pystyi näin vastaamaan STM:n vaateisiin kuntoutuksen tutkimuksen edistämiseksi. Kuntoutuksen tutkimus on tuonut merkittävästi lisäarvoa arvioitaessa terveydenhuollon vaikuttavuutta, kun tavoitteena on ihmisten paluu sairastamisen tai vammautumisen jälkeen arkeen työ- ja toimintakykyisenä ja itsenäisesti pärjäävänä kansalaisena. KUTKEn tavoite on jatkossakin olla ministeriön arvostama kuntoutuksen asiantuntija, jonka kannanottoja kuunnellaan palveluita kehitettäessä.
Miten KELA oli mukana KUTKEn alkutaipaleella?

KELA on ollut perinteisesti sekä kuntouttaja että kuntoutuksen tutkimuksen tiennäyttäjä. KUTKEn valitsema toimintamalli juontaa yhteistyöhön Kansaneläkelaitoksen (KELA) ja erityisesti sen Turussa sijainneen Kuntoutustutkimuskeskuksen kanssa. Laitos järjesti 1980- ja 90-luvuilla kuntoutustutkimusyksiköille mittavat koulutukset ja ohjasi keskussairaalat kansainväliseen yhteistyöhön. Kouluttamisen ohella KUTKElle avautuivat ovet European Forum for Research in Rehabilitation (EFRR) -järjestöön. Turun kuntoutustutkimuskeskuksen johtaja Veikko Kallio oli tämän moniammatillisen ja monitieteisen organisaation perustajajäsen. EFRR oli perustettu vuonna 1983. Perusteltua on todeta, että KUTKEn valitsemat kehittämisen ja tutkimuksen roolit sekä kansainvälinen toiminta ovat perintöä edellä mainitusta yhteistyöstä. Se loi perustan, jolta KUTKE nyt ponnistaa.

\section{Miten KUTKEn kansainvälinen} yhteistyö lähti käyntiin?

Suomi oli perustamassa EFRR:ää, ja KUTKEn yhteistyö EFRR:n kanssa sai alkunsa vuonna 1988 Rotterdamissa. Yhdistyksellämme on ollut kahdesti EFRR:n puheenjohtajuus ja sen hallituksessa on aina ollut edustajamme. EFRR edustaa maailmalla ainutkertaista moniammatillista ja monitieteistä tutkijoiden ja kuntouttajien yhteisöä. KUTKEn aloitteesta EFRR:llä on oma julkaisunsa IJRR - International Journal for Rehabilitation Reseach, joka on maailmanlaajuinen ja myös monitieteinen lehti. Sen päätoimittajana ja toimituskunnassa on ollut ja on KUTKEn edustaja. KUTKE on hoitanut kansainvälisen roolinsa niin hyvin, että EFRR:n kotipaikaksi tuli organisaation sääntöjä uudistettaessa Suomi. KUTKElla oli iso rooli sääntöjen uudistamisessa. KUTKE on EFRR:n jäsenorganisaatioista ainoa, jonka perusta on EFRR:n mukaisesti moniammatillinen ja monitieteinen. Tässäkin asiassa olemme edistyksellisiä, sillä kuntoutuksen alalla monitieteisyys on tulevaisuuden tapa toimia. EFRR järjestää kahden 
vuoden välein kansainvälisen kongressin, joka on kahdesti pidetty Suomessa vuosina 1994 ja 2015. Kansainvälinen monitieteinen yhteistyö on lisännyt varmuutta ja valanut luottamusta kuntoutuksen tulevaisuuteen, kun kilpaillaan yhteiskunnan voimavaroista.

Mikä rooli KUTKElla on ollut kansainvälisen toimintakykyluokituksen ICF:n jalkauttamisessa?

KUTKE tuki Sosiaalihallituksen pyrkimyksiä kansainvälisen toimintakykyluokituksen (ICF) istuttamisessa terveydenhuoltoomme. Sosiaalihallituksen ylilääkärin ja Työterveyslaitoksen asiantuntijoiden ajama ja WHO:n laajalla kansainvälisellä yhteistyöllä rakentama toimintakyvyn luokitus koki voimakasta vastarintaa. Se haluttiin välineeksi terveydenhuollon palvelujen vaikutusten arviointiin. Vastustajia riitti, arvostelu oli rajua ja luokitusasiantuntijat pitivät sitä käytäntöön soveltumattomana. KUTKE oli johdonmukaisesti edistämässä asiaa jäsenistönsä tuella ja järjestämällä koulutusta. Tämä tuki oli välttämätön, ja ilman sitä tuskin olisimme nykyisessä tilanteessa. Toimintakyky ja arjessa pärjääminen ovat tänä päivänä tavoiteltavia asioita terveydenhuollon toiminnan vaikuttavuutta arvioitaessa.

KUTKE vastaa lääkäreiden kuntoutuksen erityispätevyysohjelmasta yhdessä Suomen Lääkäriliiton kanssa. Milloin tämä yhteistyö alkoi, ja millaista muuta yhteistyötä on ollut kuntoutuksen koulutuksesta vastaavien tahojen kanssa?

KUTKE teki aloitteen lääkäreiden kuntoutuksen erityispätevyyden aikaan saamiseksi. Suomen Lääkäriliitto suhtautui alun alkaen myönteisesti asiaan. Lääkäriliitto perusti kuntoutuksen erityispätevyyden 31.1.2001, ja se on tällä hetkellä toiseksi suosituin lääkäreiden erityispätevyyksistä, edelle menee vain lääkärikouluttajan erityispätevyys. Kuntoutuksen erityispätevyyden käytännön asioita hoitaa KUTKEn alaisuudessa toimiva Kuntoutuksen erityispätevyystoimikunta. Lääkäriliiton ohjeissa on tarkemmin määritelty pätevyyden yleisperusteet, tavoitteet ja vaatimukset, jotka toimikunta työssään ottaa huomioon. Ne kuvaavat hyvin KUTKEn omalle toiminnalleen asettamia tavoitteita.

Yhteistyötä on ollut esimerkiksi apuvälineteknologian projekteissa Teknillisen korkeakoulun ja Taideteollisen korkeakoulun (jotka myöhemmin liitettiin Aalto-yliopistoon) kanssa. Ammattikorkeakoulujen edustajia on perinteisesti ollut KUTKEn jäsenistössä runsaasti, mikä on tarjonnut luonnollisia yhteistyökanavia.

Myös hoitajille voitaisiin kehittää kuntoutuksen erityispätevyysohjelmaa vastaava erikoistumismahdollisuus, koska kuntouttava hoitotyö on hyvin tärkeä osa kuntoutusta.

\section{Millainen KUTKE on ollut} yhteiskunnallisena vaikuttajana?

KUTKEssa on vuosien varrella voimavarojen niukkuudesta huolimatta riittänyt tarmoa myös muunlaiseen välittämiseen. Se järjesti esimerkiksi vuonna 1990 Viron itsenäistyessä laajan apuvälineiden keräyksen virolaisille kuntoutujille.

Ennen kaikkea KUTKElla on nyt sote-uudistuksen pyörteissä tärkeä vaikuttamisen paikka, ja kaikkia kuntoutuksen ammattilaisia tarvitaan mukaan toimintaan. KUTKEn vahvuutena on Tieteellisten seurain valtuuskunnan (TSV) jäsenyys, mikä kertoo vahvasta tieteellisestä taustasta ja sitoutumisesta eettisiin periaatteisiin.

Juhani Wikströmiä haastattelivat 5.10.2020:

\section{Susanna Melkas, KUTKE ry:n puheenjohtaja vuodesta 2020 Ylilääkäri, HUS Laakson neurologian klinikka Neurologisen kuntoutuksen apulaisprofessori, Helsingin yliopisto}

Sinikka Hiekkala,

KUTKE ry:n varapuheenjohtaja vuodesta 2013

ja tieteellisen toimikunnan puheenjohtaja vuodesta 2020

Tutkimusjohtaja, Invalidiliitto ry

Neurologisen kuntoutuksen dosentti,

Jyväskylän yliopisto 